\title{
Students' Perception About Warming Up in English Learning Process to Improve Students' Skills: The Case of Eighth-Grade Students at Mts Nurul Islam Pongangan Gresik
}

\author{
Rizka Safriyani \\ English Language Education Department, \\ UIN Sunan Ampel Surabaya \\ rizkasafriyani244@gmail.com \\ Ahsanatul Munawwaroh \\ English Language Education Department, \\ UIN Sunan Ampel Surabaya
}

\author{
Mahsunah \\ English Language Education Department, \\ UIN Sunan Ampel Surabaya \\ Alifa Tranei Hajizah Usva \\ English Language Education Department, \\ UIN Sunan Ampel Surabaya \\ alifatraneihu@gmail.com
}

\author{
Fifi Armita Nuriawarti \\ English Language Education Department, \\ UIN Sunan Ampel Surabaya \\ armitha.fifi98@gmail.com
}

\begin{abstract}
Warming up is a simple activity at the beginning of a meeting with students. Starting a class with a warming up activity should promote interest students, set a friendly environment, increase students' participation, and also attract students' attention. In another word, giving warming up could create students' spirit and motivation to join English learning. In this research, the researcher used collaborative games and competitive games as warming up. The purpose of this study is to explain how the students' perception of giving warming up in the English learning process to improve students' skills in English. This research used qualitative descriptive and quantitative. To collect the data, the researchers used the interview to five students in eighth-grade students at Mts Nurul Islam Pongangan Gresik and also the researcher used literature study and shared questionnaires. This result showed that $71,875 \%$ of students like learning English, although they have a problem in understanding English: speaking, writing, and fewer memories vocabulary. From the data can be said that some of the students in eight A-class interested to learn English.
\end{abstract}

Keywords: warming up, English

\section{INTRODUCTION}

Warming up is a simple activity at the beginning of a meeting with students. Starting a class with a warm-up activity can further increase interest among students, arrange a friendly environment, increase student participation, attract their attention, etc. In this warm-up activity, the most important thing is trying to show the benefits of the warm-up activity in the part why warming is important by explaining the points: establishing relationships, motivation and warm-up, attention and warm-up, background knowledge and warm-up, and objective learning and warm up.

Warming up can be done with lots of fun activities. One of the fun activities is by giving innovative educational games. The use of these games in the classroom can increase enthusiasm and strengthen the didactic information presented earlier. It is also an alternative method of teaching and exchanging information that is positive and interactive. Besides, it is suggested that team learning and active peer-to-peer instruction are greatly strengthened by educational games. According to Bailey (1999), the involvement of games in language learning can boost student participation, motivation, and eagerness in their learning. Games can also challenge students to apply the information which can enable them evaluating their critical thinking skills, as mentioned in Patil (1993) that competitive 
atmosphere can be created through the joyful and friendly environment. Moreover, Hammer \& Lee (2011) as cited in (Lam, 2014) by implementing the games, the students will not forget the moments when they played the games. Moreover, in education, using games has widely been acknowledged to engage and motivate students when it used well in classrooms. From the theory above, can be concluded that giving games as warming up is benefits in the language learning process because games help students to remember words easily, encourage their interaction, improve their communicative skills and enhance their motivation to learn English. Also, giving games like warming up are useful because they provide motivation, reduce students' stress, and give them the opportunity for real communication. According to Sunarto (2012), most students will be better able to accept the subject matter if the atmosphere of the class that occurs is not tense, relaxed, comfortable, and more friendly. Several things support the effectiveness of student learning outcomes including students learning in happy conditions, teachers use a variety of methods and techniques, using interesting and challenging learning media, adaptation to context, inductive patterns, and students as subjects in learning.

Ice-breaking in learning, lectures, or training is very helpful in creating a pleasant learning atmosphere. Icebreaking is a transition from a boring and tense situation to a more relaxed, vibrant, not sleepy atmosphere, and there is attention and there is a sense of pleasure to listen or see people talking in front of the class or meeting room (Soenarno, 2005: 1). The method can be interactively or specifically given in between or pauses in the learning process. In this case, icebreaking aims to create a learning atmosphere that is fun, serious but relaxed. Suroharjuno (2012) claimed that the objectives of warming up are as follows: directing the brain to be in alpha wave conditions ( 8 to $13 \mathrm{~Hz}$ ), rebuilding the atmosphere of learning to be more serious, relaxed and fun and not boring, maintaining the stability of the conditions of students so that their minds are fresh and easier to absorb information, removing barriers between students, so that there is no longer the assumption that there are smart students, less smart students, rich students, and so on, there are only equal opportunities to progress, the creation of dynamic conditions among students, can create excitement (motivation) among fellow students to carry out activities during group guidance. More than that, Achmad Fanani says in Journal education (2010: 69) Warming up also has benefits in its application, some of the benefits of doing icebreaking activities, including eliminating boredom, boredom, anxiety, and fatigue because it can come out temporarily from the lesson routine by doing free and cheerful motion activities, as well as other benefits such as train thinking creatively and broadly for students, develop and optimize students' brains and creativity, train students to interact in groups and work together in a team, train systematic and creative thinking to solve problems, increase self-confidence, train to determine the strategy carefully, practising creativity with limited material, practice concentration, dare to act and not be afraid of being wrong, glueing tenuous international relations, train to respect others, And also establish self-concept.

MTs Nurul Islam is one of Islamic school located in Gresik, Indonesia. The school has been applying curriculum 2013 revised. In curriculum 2013 revised students should be active students. They should have five competitions: observe, ask, apply, communicate, and think out. Most of the students at MTs Nurul Islam are less interested and less enthusiastic about learning English, and they tend to feel bored during the learning. This problem caused them less to do anything while they learn English, only listening to the teacher and doing the exercise. Besides that, they are less motivated. This problem is some with statements' of Huyen \& Nga (2003). They said that students are bored when they listen to what the teacher says, and there are no other activities during the teaching-learning process.

From these problems, we try to change their views on English subjects by applying warming up using games before the English learning process. The solution is made to increase students' interest in learning English and help their motivation in English learning process, so the teacher should have lots of games or giving warming up to create an interesting atmosphere before learning English. Therefore, giving warming up can build students' spirit to join English learning. Based on that problem, we use warming types: clapping hand, audiovisual, and songs.

Besides, some previous studies related to icebreaking can be considered for this research. First, the research was carried out by Moaddi M. Almeth-him titled, The Impact of Ice Breaking Exercises on Trainees' Interactions and Skill Acquisition: An Experimental Study. This study concludes that there is a positive impact on interaction and acquisition skills as a result of the implementation of ice breaking in the classroom.

The second study was carried out by Rotua Hutasoit, M.Pd; Drs. Bonari Tambunan, M. Hum with the title The Effect of Ice Breaking Technique in Teaching Speaking at the Tenth Grade Students of SMK Dharma Bhakti Siborongborong in Academic Year 2018/2019. Data were analyzed using the t-test formula. After calculating the data, it was found that t-test was higher than t-table $(7,70>2.005)$ with degrees of 
freedom (df) $54(28+28-2)$ with t-table was 2.005 and the calculated value was 5.38. Therefore, the null hypothesis $(\mathrm{H} 0)$ is rejected, and the alternative hypothesis $(\mathrm{Ha})$ is accepted. It can be concluded that the Ice Breaking Technique significantly influences teaching speaking.

The third study was conducted by Shinta with the title "Improving Student's Ability In Speaking Skill By Using Ice Breaker Strategy At The Second Grade Of Mts TPI Sawit Seberang In Academic Year 2017/2018. From this data analysis, it appears that the speaking skills owned by students are dramatically improved because of the ice-breaking activity in the learning process. It then depicts that positive response and high enthusiasm to study are frequently shown by students after teacher using the ice-breaking strategy in the classroom. Another research in this topic was carried out by Parisa Yeganehpour with the title Ice-breaking as A Useful Teaching Policy for Both Genders.

This study concludes that there should be an elaboration as well as a socialization for teachers about the use of ice-breaking activities in the classroom. Also, according to the findings of this study, there was no relationship between the sex of Turkish EFL learners and the effect of using icebreaker activities in improving their speaking skills.

\section{METHOD}

This study was intended to find out the answer to the formulated problem. The researcher tried to investigate how students' perception of using games as warming up in learning English process in Eight grade at MTs Nurul Islam Pongangan Gresik. The design of this research is qualitative research and quantitative research. There are thirty-two participants of this research who are from class A of Eight grade at MTs Nurul Islam Pongangan Gresik. To collect the data, the researcher used interview questions to five students randomly in eight Aclass, shared a questionnaire to thirty-two students in A-class, and literature review to support the research.

First of all, the researcher asked them about their difficulties in learning English. Secondly, they are asked about how the ways they learn English. Thirdly, they are questioned about knowledge of warming up. Fourthly, the researcher asked them about their opinion of giving warming up. And the last but not least, they asked about what the effect of warming up in their English abilities are. This research was done when the researchers did their education apprentice in MTs Nurul Islam Pongangan Gresik for two months.

The observation was done in the first week when the researchers did sit in with the English teacher while processing English learning the students were bored and their concentration was done. After that, the researcher started to look for why the students do it and they said that they were not interested in that learning because the learning was bored and monotonous. Some of them said that they needed something new in learning English. After that, the researchers look for what the interesting strategy to learn fun English is. Afterthought and consult the researchers found that they should be given warming up before or while learning English. The warming up is applied six times in the English learning process at eight A class.

In the first meeting, the researchers had given warming up in the opening section. The warming up that applied was handclapping when the researcher said Monday the students should clap hands once. When the researcher said Friday the students should clap twice and when the researchers said Wednesday the students should clap hands three times. If there were students who got wrong they got punishment and the punishment they should arrange the jumbled word that has served by researchers.

In the second meeting, the researchers used Simon says as warming up. In Simon Says warming up the students should be concentration and listen carefully because in this warming up the students should do what the researcher said if in instruction there was Simon says. When there was Simon says the students were prohibited to do what researchers said.

In the third meeting, the students were given music and they asked to walk on post-it roundly. When the music was stopping, the students should move across and stand up on post it. If students did not get post it, they got punishment and the punishment was they should write one simple sentence that contains about can or will. Next meeting the researcher used elephant and ant games. In this game, the students should embrace their finger when hearing the elephant and when hearing ant they should make a big circle with their friends consist of three people.

In the fourth meeting, the students were enjoying learning English and they were enthusiastic. In the fifth meeting, the students ask to make a line and ask to make a group consist of five people. Every group should have a writer and listener. The writer was as chief of a group and the listener was in the back of the group. The game was applied was whispering. In the final meeting, the researchers turned on the music Lily three times and asked them to listen and understand the meaning of the song. After that, the students were asked by researchers about their opinion about the meaning of Lily song randomly. During doing warming up, the English learning process was fun and the students were not bored and interested to learn English. 


\section{FINDINGS AND DISCUSSION}

\section{A. Finding}

Based on the data, in the first question, there are 23 students from 32 students who like learning English lesson. This result showed that 71, $875 \%$ of students like learning English, although they have a problem in understanding English: speaking, writing, and fewer memories vocabulary. From the data can be said that some of the students in eight Aclass interested to learn English. This result also supported by interview students randomly:

\section{Researcher: By the way, do you like learning English?}

Student 1: Actually, I am interested in learning English and I think English is fun. Although English is fun, English is also shocking because sometimes it is easy to catch and sometimes it is hard to catch. Speaking about it, I ever misunderstand with foreign because we have a different thing and different vocabulary.

Student 2: Fifty-fifty mbk, because to learn English we should know what the meaning is. Lah As you know my mom is Javanese and I live in Indonesia and I only get

English in school. Hehehe

Student 3: Yes, I like English because, in my opinion, English is quite easy to learn. Furthermore, English is also an international language. I think the English lesson is quite difficult to learn because it includes a language foreign, especially English is not my second language.

Student 4: Mmmm I like English because English is impressive. Almost countries in the world use it as languages communicate.

Student 5:I don't really like English mbk, because English is complicated. To understand the meaning I should have to know what the meaning is. Some writing and reading English is not the same.

Based on the data, in the second statement, there are 25 students from 32 students who are interested in learning English lesson using warming up. This result showed that $78,125 \%$ of students are interested in learning English using warming up. Although some of the students were not interested in this strategy, they looked to enjoy the games enthusiastically. From the data, it can be said that some of the students in eight A-class were interested to learn English. This result was also supported by the interview with students randomly:

\section{Researcher: What do you think about learning English using warming up strategy and do you interested it?}

Student 1: Yeah mbk, surely I'm very attracting with that strategy (games as warming up) because it is the first strategy that I got when learning English in this school. I never got those games and my teacher never does it before. After this, I hope my teacher will give us warming up before learning English because it is fun and the lesson will run fastly hehehehe.

Student 2: Waaah I'm very happy when you said: "we will do warming up guys using games before start learning". Yaa as a bored student I need something new in my life like games before learning English.

Student 3: Waaah surely I'm very enthusiastic about this strategy because using this strategy the teacher gives us an illustration of the material that we will learn. It is very useful to create an interesting atmosphere so I can join an English class happily and I am not bored while the English learning process. In other words, I am ready to catch the material.

Student 4: After learning English with this strategy is quite helpful, because it can make me able to speak English.

Student 5: Yes, after learning with this strategy I more like English because this is one of the ways to make the students do not feel bored when learning English.

Based on the data, in the third statement, there are 32 students from 32 students who agree when warming up is applied in learning English lesson. This result showed that $100 \%$ of students in eight A-class agree if every learning English use warming up. This result also supported by interview students randomly: 
memories five until ten new vocabularies easily. Thanks ya mbk!

Students 3: I am very thank you mbk, because you use warming up before the English learning process my English abilities are increasing. Today I able to write the right vocabulary without cheat at dictionary. Besides that, my vocabulary is increasing and also my confidence is up.

Students 4: Alright mbk, after learning English with this strategy I increasingly prefer English, because with this strategy it can increase the vocabulary that I have. By using this strategy, I can find out vocabulary that I didn't know before. Because some lot of vocabulary that I feel is unfamiliar to me.

Students 5: In my opinion, using this strategy in learning English can improve all my English skills, starting from speaking, listening, writing, and reading. I think this strategy can also make the classroom come alive and not seem monotonous.

Table 1:

The result of the questionnaire about students' perception of warming up in the English learning process to improve students' skills.

\begin{tabular}{|r|l|l|l|}
\hline NO. & STATEMENT & $\begin{array}{l}\text { FREQU } \\
\text { ENCY }\end{array}$ & $\begin{array}{l}\text { PERC } \\
\text { ENTICE }\end{array}$ \\
\hline 1. & $\begin{array}{l}\text { I like learning } \\
\text { English }\end{array}$ & $71,875 \%$ \\
\hline 2. & $\begin{array}{l}\text { I more } \\
\text { enthusiasm in } \\
\text { learning } \\
\text { English }\end{array}$ & $\begin{array}{l}78, \\
125 \%\end{array}$ \\
\hline $\begin{array}{l}\text { using warming } \\
\text { up in before } \\
\text { learning } \\
\text { process }\end{array}$ & $\begin{array}{l}\text { I agree if } \\
\text { warming up } \\
\text { always apply in } \\
\text { learning } \\
\text { English } \\
\text { meeting }\end{array}$ & 32 & $100 \%$ \\
\hline \multicolumn{2}{|l}{} & \\
\hline
\end{tabular}

Students 2: Alhamdulillah after learning English using warming up my English is up. Before using this strategy my vocabulary is bad but after joining this strategy my vocabulary is up until $25 \%$. Now I can
Students 1: Uups sorry mbk, oke after learning English using warming up my abilities in English is up. Especially my vocabulary is up and now I able to pronounce vocabulary rightly.

\section{Researcher: Do you agree if the English teacher} there are 3 students from 32 students whose speaking ability is increasing. They said that before warming they cannot speak using English. This factor because they did not memorize lots of in eight Aclass improving in speaking after join From five students in thirty-two students in eight, A class improves in writing ability. It means that $15,625 \%$ of students in that class are up.

Besides writing ability and speaking ability are increasing, their reading ability is improved. From the data, they are two students who feel it and twenty-two students who improve in vocabulary. These results are supported by interview students randomly:

Researcher: After warming, what is the effect for you? 


\begin{tabular}{|c|c|c|c|}
\hline 4. & $\begin{array}{l}\text { I am interested } \\
\text { to learn English } \\
\text { using warming } \\
\text { up }\end{array}$ & 29 & $90,625 \%$ \\
\hline 5. & $\begin{array}{l}\text { After } \\
\text { warming up, } \\
\text { my ability } \\
\text { speaking is } \\
\text { up }\end{array}$ & 3 & $9,375 \%$ \\
\hline 6. & $\begin{array}{l}\text { After warming } \\
\text { up my writing } \\
\text { ability is up }\end{array}$ & 5 & $15,625 \%$ \\
\hline 7. & $\begin{array}{l}\text { After warming } \\
\text { up my reading } \\
\text { ability is up }\end{array}$ & 2 & $6,25 \%$ \\
\hline 8. & $\begin{array}{l}\text { After warming } \\
\text { up my } \\
\text { vocabulary is } \\
\text { up }\end{array}$ & 22 & $68,75 \%$ \\
\hline 9. & $\begin{array}{lr}\text { After } & \text { warming } \\
\text { up } & \text { my } \\
\text { selfconfident is } \\
\text { up }\end{array}$ & 30 & $93,75 \%$ \\
\hline
\end{tabular}

\section{B. Discussion}

Using warming up in processing English learning. Learning English will be easy to accept because learning is more relax and not scary. This result is like-minded with Sunarto (2012), he says that most students will be better to accept the subject matter if the atmosphere of the class that occurs is not tense, relaxed, comfortable, and more friendly. In other words, giving warming in the first step of learning will create their mood to learn English appear and it will attract them to be ready to join English.

Based on the data, in the fifth statement, there are 3 students from 32 students whose speaking ability is increasing. They said that before warming they can not speak English. This factor is because they did not memorize lots of vocabulary. After joinwarming up, their speaking ability is improved because in warming the students who failed ingame will get punishment. The punishment is they should look for a partner and invite them to do simple conversation. Besides that, the atmosphere and motivation to learn English is also supported. From the data can be seen that $9,37 \%$ of students in eight A-classes improving in speaking after join warming up before learning the English process. This result is supported by Shinta.

Shinta has conducted this research with title improving student's ability in speaking skills by using ice breaker strategy at the second grade of
Mts TPISawit Seberang in the academic year 2017/2018. From this data analysis, it appears that there is an increase in students' speaking skills. This data can be seen from the average Post-Test II is 80.3. In other words, students' speaking skills have improved. Based on qualitative data, students gave a good response and showed enthusiasm after using the Ice breaker strategy in speaking skills.

Also, using giving warming up in learning English, they can increase their confidence. This result is like-minded with Achmad Fanani says in Journal education (2010: 69) Warming up also has benefits in its application, some of the benefits of doing ice-breaking activities, including eliminating boredom, boredom, anxiety, and fatigue because it can come out temporarily from the lesson routine by doing free and cheerful motion activities. Besides that, using warming up in learning English can increase their vocabulary. This result is likeminded with Hammer \& Lee (2011) as cited in (Lam, 2014) by implementing the games, the students will not forget the moments when they played the games.

Moreover, in education using games has widely been acknowledged to engage and motivate students when it used well in classrooms. From the theory above, can be concluded that giving games as warming up is benefits in the language learning process because game help students to remember words easily, encourage their interaction, improve their communicative skills and enhance their motivation to learn English. Also, giving games like warming up are effective because they provide motivation, lower students' stress, and give them the opportunity for real communication.

\section{CONCLUSION}

Based on the results and discussion of the study, it can be concluded that learning that uses ice-breaking applications can affect students learning outcomes in learning English. This is proved by their responses, in which the researchers have conducted a process of interviewing students. There are thirty-two students in eight A class who agree that warming up is good to be applied in learning English process. Warming up can increase their ability in English, especially their speaking ability, vocabulary and their motivation to learn English. In short, based on these benefits, it is clear that warming up can be an alternative used in learning so that learning does not seem monotonous and not boring for students.

\section{REFERENCES}

[1] Allen, D.E., \& Vallette, R.M. Classroom Techniques: Foreign Languages and English as Second Language. New York: Harcourt Grace Jovanovich, 1997. 
[2] Almeth, H., \& Moaddi, M, The Impact of Ice Breaking Exercises on Trainees' Interactions and Skill Acquisition: An Experimental Study.JKAU: Econ. \& Adm., Vol. 23 No. 1, pp: 3-20 (2009 A.D./1430 A.H).

[3] Avedon, M.E., \&Brian, B.S. Learning through Games. The Study of Games. New York: John Wiley \& Sons, Inc: pp 315-321, 1971. [4] Carrier, M. Take 5: Games and Activities for the Language Learner, UK: np. Pp 6-11, 1990.

[4] Eggleston, T., \& Smith, G. Building Community in the Classroom through Ice-Breakers and PartingWays: Society for the Teaching of Psychology, Retrieved July 07, 2017, 2004.

[5] Flanigan, E. The importance of ice breaking and warm-up activities in English class. Creative games for the language class by Lee Sukim, (Forum) vol. 33 No 1, January-March 1995, 2011.

[6] Garris, R., Ahlers, R., \& Driskell, J. E. Games, motivation, and learning: A research and practice model. Simulation \& Gaming, 33(4), 441-467, 2002.

[7] Hutasoit, R., \& Tambunan, B. The Effect of Ice Breaking Technique in Teaching Speaking at the Tenth Grade Students of SMK Dharma Bhakti Siborongborong in Academic Year, International Journal of English Literature and Social Sciences, Vol-3, Issue-5, Sept-Oct, 2018 III, 2018/2019. [9] Said, M. 80 + Ice Breaker GamesKumpulan Permainan Penggugah Semangat, Yogyakarta: Andi Offset, 2010.

[8] Saputra, B.J., \& Marzuki. The Comparison of Speaking Achievement Using Ice Breaker Games With Media AudioVisual on the student's os SMA: Vol 2. No 1, April 2013.

[9] Sinta, Improving Student's Ability In Speaking Skill By Using Ice Breaker Strategy At The Second Grade Of Mts Tpi Sawit Seberang In Academic Year 2017/2018, North Sumatra: Thesis, 2018. [12] Sunarto, Ice breaker Dalam pembelajaran aktif, Surakarta: Cakrawala Media, 2012.

[10] Wright, A., Betteridge, D., \& Buckby, M Games for language learning, (second edition), Cambridge University Press, 1984. 